\title{
Chapter 15 \\ Habitat Changes Caused by Sea Level Rise, Driven by Climate Change in the Northern Adriatic Coastal Wetlands, Slovenia
}

\author{
Mitja Kaligarič and Danijel Ivajnšič
}

\subsection{Seacoast and Climate Change}

Coastal zone, as a boundary between sea and land is the most dynamical and sensitive area, which comprises a great variety of natural ecosystems and resources (Palazov and Stanchev 2006). Coastal habitats are already one of the most severely endangered habitats due to intensive land-use changes occurring during the last decades. Most changes are driven by tourism, which has caused substantial destruction of most endangered habitats such as coastal dunes. The second threat is increasing area of ports, which require more and more space for containers or car terminals. Urbanisation in general has caused an important pressure to coastal areas, which offer higher living standards, better economic conditions, job and education possibilities and favourable climate. Therefore, immigration pressure to coastal areas is substantial. Besides that, there is also agriculture, developed in adjacent areas to the coast, driven by favourable climate and increased requirement of fresh products. The constantly increasing anthropogenic pressure is additionally intensified by climate change effects, among which the sea level rise is a serious threat. Sea level rise is a parameter which - in contrast to many other climatic parameters, being also congruent among - is showing quite clear trends. However, factors which cause changes in morphology of coasts are numerous and include sediment supply, tidal currents, wave action, extreme weather events (Cooper and Pilkey 2004), and also the subsidence of the surface (Lambeck et al. 2004). Baustian et al. (2012) reports that in certain situation, such as high sedimentation of both organic and inorganic materials coastal wetlands may be able to keep pace with rising sea level. There are different projections of the sea level rise in different coastal areas across the globe; thus the only relevant basis for reliable predictions are local measurements on the concrete studied sites. For instance, one study in

M. Kaligarič $(\varangle) \cdot D$. Ivajnšič

Department of Biology, Faculty of Natural Sciences and Mathematics,

University of Maribor, Koroška cesta 160, SI-2000 Maribor, Slovenia

e-mail:mitja.kaligaric@uni-mb.si; dani.ivajnsic@uni-mb.si 


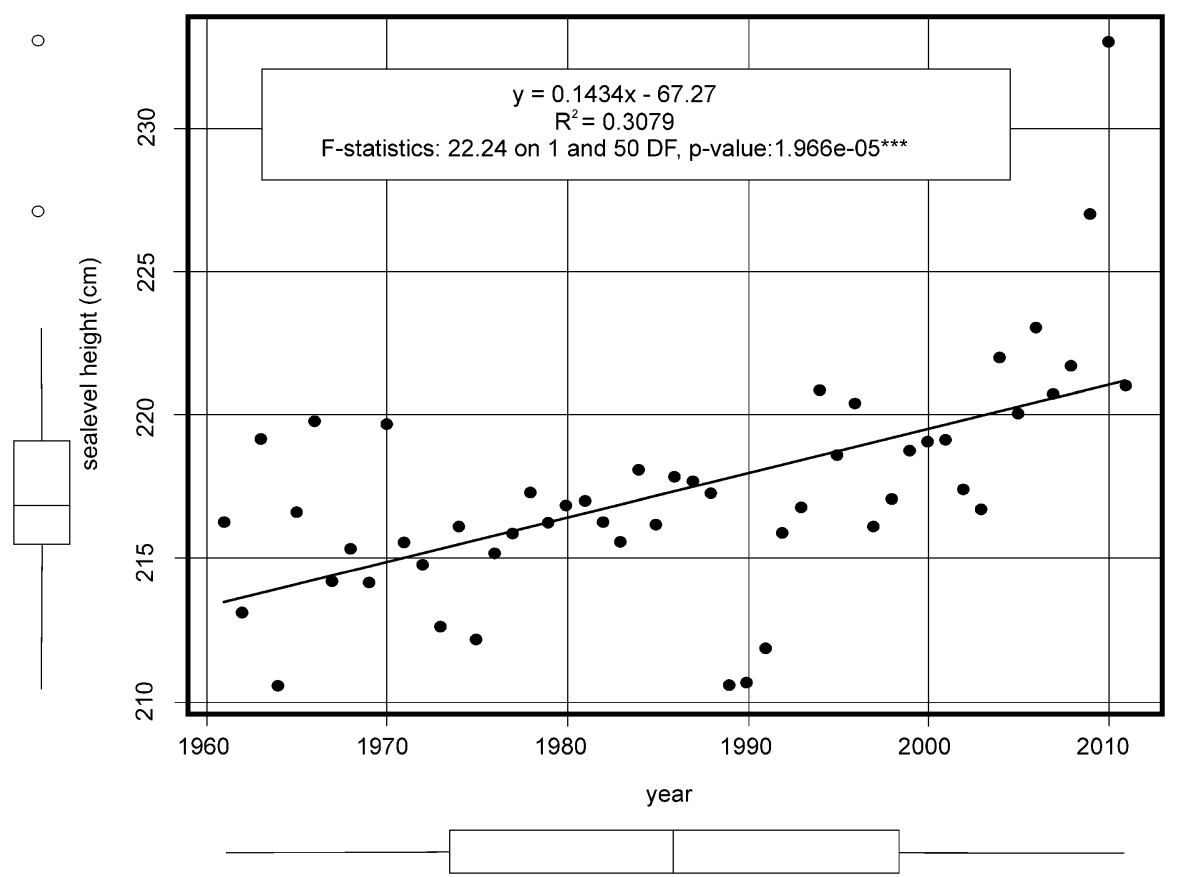

Fig. 15.1 Average sea level trend $\left(0.14 \mathrm{~cm} \mathrm{year}^{-1}\right)$ and some statistical parameters for the sea level height measuring station Koper (1961 to 2011; ARSO 2012)

Australia (Elumpe Akumu et al. 2011) demonstrated that a metre rise in sea level could decrease inland fresh marshes from 225.67 to $168.04 \mathrm{~km}^{2}$ by the end of the century.

In that light we wanted to address the following research questions in the present study: (1) Is sea level rise a serious threat for coastal wetlands on the sedimentary coast of the Northern Adriatic - what are the trends of sea level rise in the nearest measuring point to the two coastal protected areas with Natura 2000 (N2000) habitat types? (2) Do the present spatial distribution of coastal habitat types (a habitat map) match with micro-elevations (digital elevation model)? To which extend? (3) Is it possible to develop a relevant habitat transition model using different scenarios of sea level rise? (4) Which mitigation measures are feasible?

The data about sea level rise are available from the sea level height measuring station Koper from year 1961 to year 2011 (ARSO 2012; Fig. 15.1). But the trend of sea level rise is more realistic when divided in two intervals. The first one from 1961 to 1985 is not statistically significant $\left(\mathrm{p}=0.247\right.$, slope $\left.=0.02 \mathrm{~cm} \mathrm{year}^{-1}\right)$; however, the second one from 1986 to 2011 shows strong statistical significance ( $\mathrm{p}=0.0003$, slope $=0.43 \mathrm{~cm}$ year $^{-1}$; Fig. 15.2).

During the twenty-first century, global average sea level is expected to rise considerably faster than in the 20th, even if a common conclusion from all the coupled atmospheric-ocean general circulation models is that the sea level change 


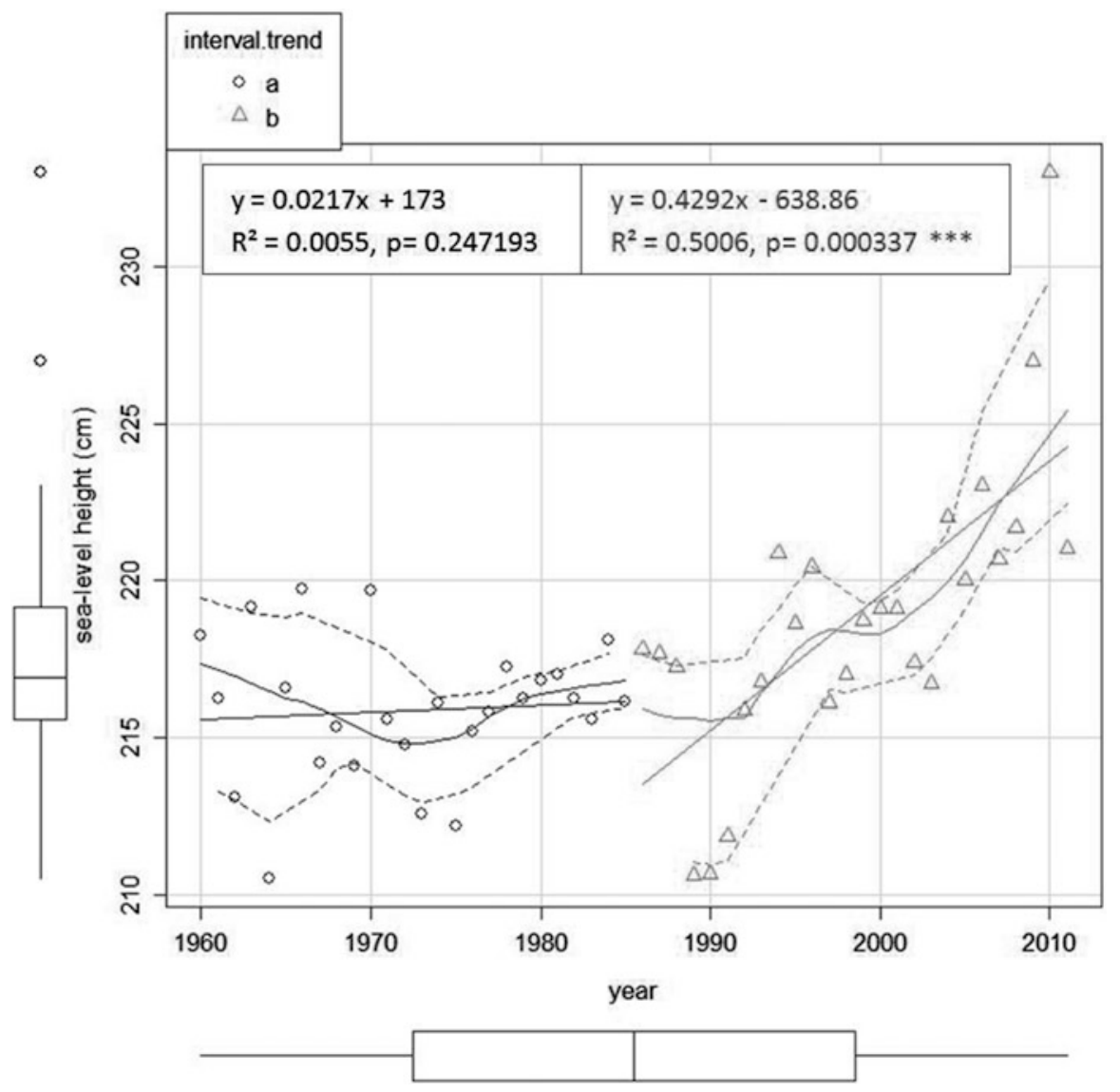

Fig. 15.2 Trend of sea level rise, divided into two intervals, where the latter shows statistical significance $\left(\mathrm{p}=0.0003\right.$, slope $\left.=0.43 \mathrm{~cm} \mathrm{year}^{-1}\right)$

will be far from uniform (Gregory et al. 2001; IPCC 2007). Thus, we believe that it is more proper to use the second trend - although very pronounced - to predict the time when the habitat transition scenarios in both study areas will occur.

It is also possible to make predictions of time frames (year \pm standard error) according to the sea level rise scenarios with two different sea level trends in Koper (Table 15.1).

We can assess from the above shown data that the scenarios will be realised in quite short time if the trends (1960-2011 and 1986-2011) will continue. Comparable results have been shown also for global sea level rise (e.g. Church et al. 2008). That means that the countermeasures to mitigate the habitat changes should be planned for a period of 10-20 years from now if we aim to prevent drastic changes. 
Table 15.1 Prediction of time frames (year \pm standard error) according to the sea level rise scenarios with two different sea level height trends in Koper

\begin{tabular}{llllllll}
\hline & & \multicolumn{5}{l}{ Rising sea level scenarios } \\
\cline { 5 - 8 } ST & $\mathrm{a}$ & $\mathrm{M}$ & Trend & L 5 cm & L $10 \mathrm{~cm}$ & L 15 cm & L 20 cm \\
\hline Koper & $1960-2011$ & 1 & $\mathrm{Y}=0.1434 \mathrm{X}-67.27$ & $2045 \pm 3.31$ & $2080 \pm 3.48$ & $2115 \pm 3.78$ & $2150 \pm 4.10$ \\
Koper & $1985-2011$ & 2 & $\mathrm{Y}=0.4292 \mathrm{X}-638.86$ & $2015 \pm 1.34$ & $2027 \pm 1.62$ & $2038 \pm 1.89$ & $2050 \pm 2.16$ \\
\hline
\end{tabular}

$\mathrm{L} \mathrm{5,} \mathrm{L} \mathrm{10,} \mathrm{L} 15$ and L $20 \mathrm{~cm}$ : sea level rise scenarios for 5, 10, 15 and $20 \mathrm{~cm}$

$S T$ sta-tion, $a$ year, $M$ model, $L$ sea level rise scenarios

\subsection{The Investigated Areas}

The two most important coastal wetlands in Slovenian seacoast are Sečovlje Salina (Sečoveljske soline) and Škocjan Inlet (Škocjanski zatok). Sečovlje salina area is a Nature Park established in 2002, which covers about 650 ha along the SloveneCroatian boundary in the extreme south-western part of Slovenia. Its northern part, where active salt-making is still taking place, is called Lera. From the Park's southern part, called Fontanigge, it is separated by the bed of the Drnica stream. The Fontanigge is full of large basins which, are being gradually overgrown by different types of halophile vegetation; many of them are classified as Natura 2000 habitats. The main freshwater vein is the Dragonja River, which after few tens of kilometres joins the sea at the Sečovlje salt-pans and creates a small estuary. Despite the salina having been made by man in early Middle Ages, it is a mosaic of natural habitats today, which contains not less than 6 Natura 2000 habitat types!

Škocjan Inlet Nature Reserve is a Mediterranean wetland established in 1998 and covering an area of 122 ha. Located at the outskirts of the town of Koper, the reserve is commonly known as 'the green heart of Koper'. After the restoration in 2007, Škocjan Inlet has regained its past biodiversity or it has even been improved in terms of surface of coastal Natura 2000 habitats. After the vegetation succession period of five years a lagoon with artificial islets at different altitudes enabled - the development of mainly two valuable habitats dominated with halophytes.

\subsection{Targeted Natura 2000 Habitats}

There are two non-vegetated habitat types which are important predominately for marine fauna and birds. Estuaries (N2000 code 1130, PAL.CLASS.: 13.2, 11.2) are considered as a marine habitat and actually were not a subject of our study. There are three estuarine habitats in the Sečovlje Salina and none in Škocjan Inlet. "Mudflats and sandflats not covered by seawater at low tide" (N2000 code 1140, PAL.CLASS.: 14) constitute a habitat type, widespread in both investigated areas, important mainly for bird nesting and feeding. In both areas we can find very small patches of the "tall rush salt marshes (communities of Juncetaliamaritimi)" or "rush salt marshes dominated by Juncusmaritimus and/or J. acutus" (N2000 code 
1410, PAL.CLASS: 15.6 or 15.51). The tall rush salt marshes occur in a water regime similar to freshwater marshes dominated by freshwater Juncus species. The inflow of fresh saltwater is essential to maintain a certain level of nutrients in these marshes. Small patches of "Spartina swards (Spartinionmaritimae)" (N2000 code 1320, PAL.CLASS.: 15.2) occur at the edge of the Sečovlje Salina area, where this type colonise the stable muddy islets at the mouth of the Dragonja river, disturbed at high tide and by sea turbulence. It was found also in similar conditions along the lower part of the S. Giorgio channel close to its mouth. It supports also brackish water, which should be rich in nutrients.

The most widespread and also the most ecologically extreme coastal wetland habitat type vegetated with vascular plants, is "Salicornia and other annuals colonizing mud and sand" (N2000 code 1310, PAL.CLASS: 15.1). It is formed mostly of halophyte annuals, where annual glassworts (Salicornia spp.) are dominant. This habitat occurs on periodically inundated mudflats or sand. It is characterised by poor - soil nutrient status, low oxygen conditions and exposure to the regular tidal regime. Although this glasswort-dominated vegetation is considered as one habitat type, it consists of two types, each dominated by one glasswort species: Salicornia patula, a diploid, and Salicornia emerici, a tetraploid. The second habitat type, developed on higher micro-elevation, is "Mediterranean and thermo-Atlantic halophilous scrubs (Sarcocornetea fruticosi)" (N2000 code 1420, PAL.CLASS.: 15.6). It is composed of perennial halophytes. The dominant plants are Halimione portulacoides, Inula critmoides, Limonium angustifolium, Atriplex hastata, Artemisia coerulescens and shrubby Sarcocornia (Arthrocnemum) species (S. fruticosa and A. glaucum). It occurs mainly at the edges of the abandoned salt pans of the Sečovlje salina, on elevated sites, banks and enclosed muddy surfaces with only temporary inundation.

\subsection{Methods}

Different methods were used address the scientific questions set within this study from field vegetation mapping, field geodetic measurements, LIDAR scanning to spatial statistics.

- Habitat mapping (PHYSIS typology, $1 \mathrm{~m}$ resolution)

The PHYSIS typology, based on Palaearctic classification (Devilliers and Devilliers-Terschuren 1996), was chosen as one of the most accurate for habitat mapping. The hierarchically based PHYSIS enables us to refine the habitat type with additional information about the vegetation level. This classification was adopted and modified for Slovenian conditions (Jogan et al. 2004). The 'hybrids' (transitional forms, mixtures or mosaics) between two habitat types were also used in field mapping. The PHYSIS typology is also the ground for FFH codes (Natura 2000 codes).

- Determination of micro-elevations (two methods: geodetic; LIDAR) 
Geodetic measurements were carried out by a professional geodesist, using a high resolution GNSS (Global Navigation Satellite System) instrument with geodetic of $1 \mathrm{~cm}$. Afterwards we scanned the study area with LIDAR technology. The data were taken from $650 \mathrm{~m}$ height with a recording frequency of $142 \mathrm{kHh}$ and a flight speed of $85 \mathrm{kts}$. Thus we obtained an average point density of 4 points per square metre and a horizontal accuracy of $10 \mathrm{~cm}$.

- Attribution of micro-elevation intervals to mapped habitat types

We used the ArcGIS Spatial analyst tool to combine the elevation data with the habitat type map and thus define the micro-elevation intervals for each habitat type aggregate. The modelled scenarios are therefore very dependent on the morphology of the study area relief.

- Habitat transitions model (ArcGIS, Idrisi Selva software)

We built a GIS-based habitat transition model to predict the spatial distribution of protected habitats according to the sea level trend and prior to defined scenarios of sea level rise $(5,10,15$ and $20 \mathrm{~cm})$.

\subsection{Habitat Shifts and Habitat Loss According to Different Scenarios of Sea Level Rise}

We built a prediction model which demonstrated to which degree, how and where coastal habitats will shift to each other and decrease their surfaces in total. In Sečovlje Salina the GNSS geodetic method was applied to obtain micro-elevations in different habitat types. Only then the four scenarios of sea level rising have been applied (Fig. 15.3).

In Tables 15.2 and 15.3 the percentage shares of the habitat type areas (based on 2010 mapping) and the modelled scenarios of sea level rise in Sečovlje Salina and Škocjan Inlet study areas are shown.

As outlined in the methods section, the results are dependent on the micro-relief structure of the study area and therefore they differ from each other. In Sečovlje Salina Natural Park, the area of N2000 habitat type - "mudflats and sandflats not covered by seawater at low tide (code 1140)" - is decreasing in all modelled scenarios (L 0-L $20 \mathrm{~cm}$ ). This habitat type will lose almost $54 \%$ of the predicted area. Compared to Škocjan Inlet Nature Reserve, the same habitat will gain a few percentage points in area in the case of sea level rise of 5, 10 and $15 \mathrm{~cm}$, and will then decreases when the water rises by $20 \mathrm{~cm}$, representing just $6 \%$ of the total area.

In both areas the Mediterranean glasswort swards (N2000 code 1310) are decreasing in land cover, except for the scenario involving a sea level rise of $10 \mathrm{~cm}$ in Sečovlje Salina Nature Park, where the percentage area increases to almost $21 \%$. The habitat type where we detected the largest difference in predicted spatial distribution is the Mediterranean saltmarsh scrubs (N2000 code 1420). In Skocjan Inlet Nature Reserve, this habitat covers $7 \%$ of the total area. If the sea level rises by $5 \mathrm{~cm}$, the habitat type will represent almost $25 \%$ of the reserve area. The predicted area then decreases at the next stage of sea level rise, but it still represents a greater percentage of the area than at present time. In Sečovlje Salina Nature Park 


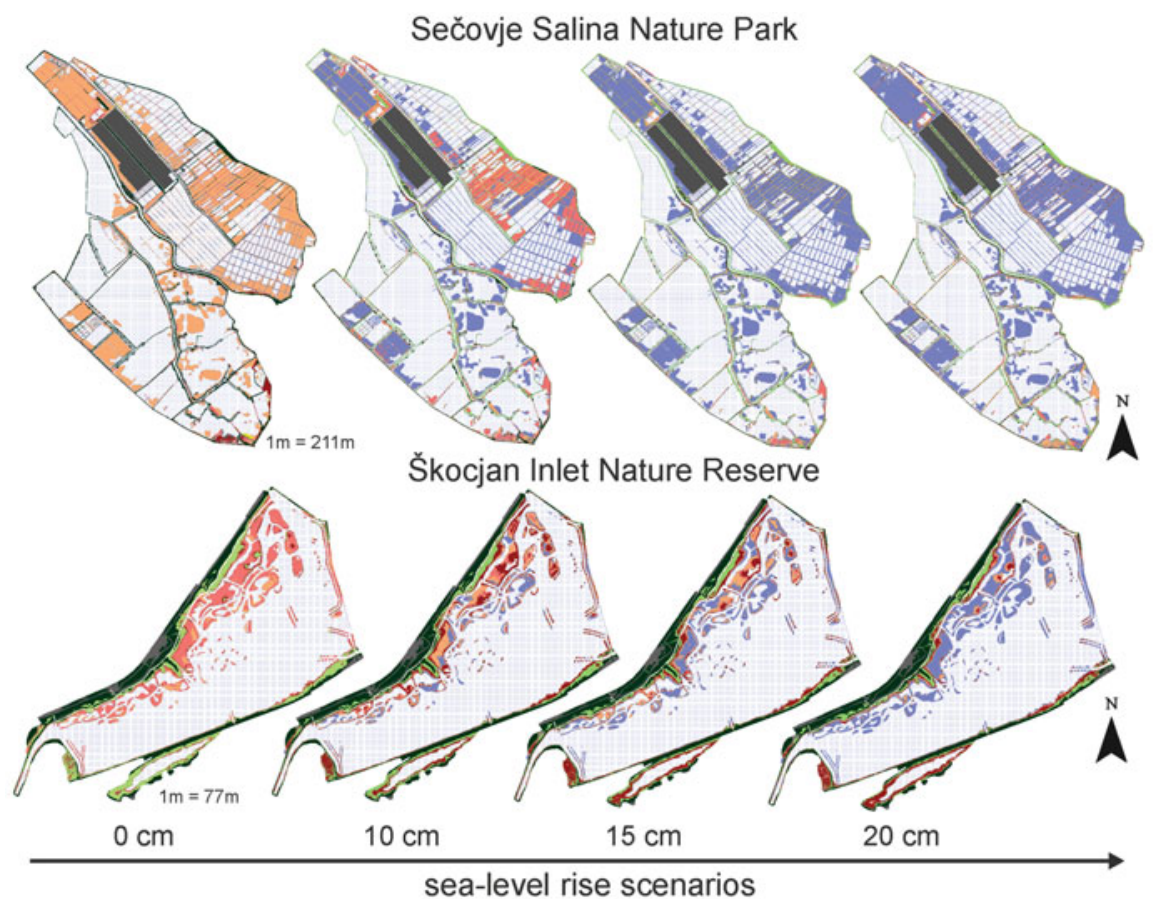

\section{Legend:}

\begin{tabular}{l|l|}
\hline Mudflats and sandflats not covered by seawater at low tide (1140) & Submediterranean scrub \\
\hline$\square$ Mediterranean glasswort swards (1310) & Other \\
Mediterranean saltmarsh scrubs (1420) & Water (after seal-level rise scenarios) \\
\hline Phragmites stands & Water \\
Ruderal stands & Wedranean salt meadows (1410)
\end{tabular}

Fig. 15.3 Predicted spatial distributions of habitat types (aggregates) in the case of sea level rise for $0,10,15$ and $20 \mathrm{~cm}$ in Sečovlje Salina Nature Park and Škocjan Inlet Nature Reserve study areas

Table 15.2 Percentages of habitat type area according to 2010 mapping and the modelled scenarios of sea level rise in Sečovlje Salina Nature Park study area

\begin{tabular}{lrrrrrr}
\hline Sečovlje Salina Nature Park study area & \multicolumn{7}{c}{ Sea level rise scenarios } \\
\cline { 5 - 7 } Habitat type & L 0 cm & L 5 cm & L 10 cm & L 15 cm & L 20 cm \\
\hline Mudflats and sandflats not covered by seawater & 56.56 & 22.25 & 7.13 & 5.94 & 3.28 \\
$\quad$ at low tide (1140) & & & & & \\
Mediterranean glasswort swards (1310) & 7.70 & 8.01 & 20.76 & 3.54 & 5.46 \\
Mediterranean saltmarsh scrubs (1420) & 2.13 & 0.61 & 0.57 & 0.75 & 2.36 \\
Phragmites stands & 2.49 & 4.21 & 0.57 & 15.51 & 13.15 \\
Ruderal stands & 16.23 & 13.79 & 14.54 & 1.19 & 1.10 \\
Submediterranean scrub & 0.47 & 0.46 & 0.45 & 0.45 & 0.46 \\
Other & 14.09 & 13.94 & 13.79 & 13.64 & 13.48 \\
Water & 0.01 & 0.35 & 37.53 & 57.32 & 59.54 \\
Mediterranean salt meadows (1410) & 0.32 & 36.38 & 2.30 & 1.66 & 1.17 \\
\hline
\end{tabular}

$\mathrm{L} 0 \mathrm{~cm}$ : habitat types defined with relative micro-elevation

$\mathrm{L} 5$, L 10, L 15 and L $20 \mathrm{~cm}$ : sea level rise scenarios for 5, 10, 15 and $20 \mathrm{~cm}$

$L$ sea level 
Table 15.3 Percentages of habitat type area according to 2010 mapping and the modelled scenarios of sea level rise in Škocjan Inlet Nature Reserve study area

\begin{tabular}{|c|c|c|c|c|c|}
\hline Sečovlje Salina Nature Park study area & Sea leve & el rise sce & enarios & & \\
\hline Habitat type & $\mathrm{L} 0 \mathrm{~cm}$ & $\mathrm{~L} 5 \mathrm{~cm}$ & $\mathrm{~L} 10 \mathrm{~cm}$ & $\mathrm{~L} 15 \mathrm{~cm}$ & L $20 \mathrm{~cm}$ \\
\hline $\begin{array}{l}\text { Mudflats and sandflats not covered by seawater at } \\
\text { low tide (1140) }\end{array}$ & 7.23 & 11.17 & 14.02 & 13.16 & 5.89 \\
\hline Mediterranean glasswort swards (1310) & 33.53 & 8.26 & 7.48 & 4.84 & 3.75 \\
\hline Mediterranean saltmarsh scrubs (1420) & 3.75 & 24.56 & 18.87 & 14.87 & 12.43 \\
\hline Phragmites stands & 22.47 & 17.70 & 15.35 & 16.36 & 11.99 \\
\hline Ruderal stands & 25.22 & 26.73 & 26.39 & 25.94 & 25.41 \\
\hline Other & 7.80 & 7.21 & 6.63 & 6.14 & 5.66 \\
\hline Water & 0.00 & 4.36 & 11.85 & 21.71 & 34.87 \\
\hline
\end{tabular}

$\mathrm{L} 0 \mathrm{~cm}$ : habitat types defined with relative micro-elevation

$\mathrm{L} \mathrm{5,} \mathrm{L} \mathrm{10,} \mathrm{L} 15$ and L $20 \mathrm{~cm}$ : sea level rise scenarios for 5, 10, 15 and $20 \mathrm{~cm}$

the same habitat covers just around $7 \%$ of the total area and will (L 5, L 10 and L $15 \mathrm{~cm}$ ) lose more than a half of its recent land cover in the predicted scenarios. In the worst case scenario, the habitat will gain some space and will represent $0.23 \%$ more area than today. The overall reduction of coastal habitats was already described as "coastal squeeze" in Australia (Bayliss et al. 1997) - obstacles, roads or settlement prevent the landward migration of some ecosystems such as salt marshes.

Prediction of the spatial distribution of the Phragmites stands is problematic. The correlation coefficient between the relative elevation and the Phragmites stands habitat area cover is one of the lowest, or - in other words - the frequency distribution of the relative heights is far from normal, which means that the habitat occurs in almost all relative elevation zones. Thus, it is difficult to predict its spatial distribution according to sea level rise scenarios. However, we did manage to model the Phragmites stands in both study areas, the results, however, are surprising. In Škocjan Inlet Nature Reserve the habitat constantly decreases in area (from 22 to $12 \%$ of the total area) within the sea level rise gradient. In Sečovlje Salina Park the results indicate the opposite situation. According to the model the habitat gains space from its current 2.5 to $15.5 \%$ in the $\mathrm{L} 15 \mathrm{~cm}$ and finally $13 \%$ in the worst case scenario. In all the scenarios modelled the habitat's ruderal stands, sub-Mediterranean scrub and "other" maintain a constant percentage of spatial cover.

We have to point out the N2000 habitat type Mediterranean salt meadow (1410), which occupies less than $1 \%$ of the total area in Sečovlje Salina Nature Park. The model results do not realistically represent its spatial distribution because we could not measure the real relative elevation on which it occurs. The habitat aggregate is constructed almost exclusively of Juncus maritimus plants, which grows in water.

All the model results are much more reliable for Śkocjan Inlet Nature Reserve, due to its far more natural topography and because we scanned the whole area using the LIDAR technology and a high resolution geodetic GNSS to calibrate the dense LIDAR point cloud data. 


\subsection{How to Preserve Coastal Habitats in the Future?}

It could be concluded from this study that sea level rise is a serious threat to coastal wetlands in the Northern Adriatic. It revealed that the spatial distribution of habitat types follows the micro-elevations and therefore a habitat transition model could be developed. The prediction model demonstrated to which degree, how and where coastal habitats will shift to each other and decrease their surfaces in total. It was summarised already by Nicholls et al. (1999) that there is need to start strategic planning of appropriate responses immediately in order to prevent the wetland loss. The countermeasures should take three directions, depending on the natural features of each area.

Where there is a shallow sedimentary coast, the creation of artificial islets at desired micro-elevations, suited to specific habitat types is possible. In such areas, artificial islets, fitted within natural bays of lagoons, would function in a completely natural manner. The islets should be carefully levelled to a certain micro-elevation and consolidated at the edges with wooden kerbs. This method has already proven to be efficient in the renaturation of Škocjan Inlet. In some cases the coastal habitats are shaped geometrically, developed in artificial man-made structures (abandoned ports, coastlines, Salinas etc.). In such cases the artificial islets can also consist of rectangular or any other regularly-shaped structure.

The second possibility is only appropriate where there is enough space in the buffer zone of coastal wetlands: if the shore is not too steep, we simply wait for the effects of sea level rise (waves, elevated salinity and moisture) to reach the higher zones, where new halophyte habitats will be established. This process could also be facilitated by removing the ruderal vegetation and preparing the suitable elevation.

The third possibility is only applicable in rare cases, where it is possible to regulate the sea level in areas with targeted habitats, using artificial sea barriers. This is already partially possible in the Sečovlje salina area: to some internal sections not directly connected with the open seawater, the influx of water comes through channels that are artificially regulated. However, because the surface in the Sečovlje salina covered with Natura 2000 habitats is already minimal, we suggest also creating artificial rectangular islets inside the largest salt-pans (water reservoirs).

Open Access This chapter is distributed under the terms of the Creative Commons Attribution Noncommercial License, which permits any noncommercial use, distribution, and reproduction in any medium, provided the original author(s) and source are credited.

\section{References}

Baustian, J. J., Mendelssohn, I. A., \& Hester, M. W. (2012). Vegetation's importance in regulating surface elevation in a coastal salt marsh facing elevated rates of sea level rise. Global Change Biology, 18, 3377-3382. 
Bayliss, B., Brenman, K., Elliot, I., Finlayson, M., Hall, R., House, T., Pidgeon, B., Walden, D., \& Waterman, P. (1997). Vulnerability assessment of predicted climate change and sea level rise in the Alligator Rivers region, Northern Territory, Australia (Supervising Scientist Report 123). Canberra: Supervising Scientist.

Church, J. A., White, N. J., Aarup, T., Wilson, W. S., Woodworth, P. L., Domingues, C. M., Hunter, J. R., \& Lambeck, K. (2008). Understanding global sea levels: Past, present and future. Sustainability Science, 3, 9-22.

Cooper, J. A. G., \& Pilkey, O. H. (2004). Sea level rise and shoreline retreat: Time to abandon the Bruun rule. Global and Planetary Change, 43, 157-171.

Devilliers, P., \& Devilliers-Terschuren, J. (1996). A classification of Palearctic habitats (pp. 1-194). Strasbourg: Council of Europe.

Dolgoletni niz višin morja ARSO. (2012). AgencijaRepublikeSlovenijezaokolje [Long year sea level height data set, Slovenian environment agency, Ministry of the environment and spatial planning]. Available at: http://kazalci.arso.gov.si/?data=indicator\&ind_id=146. Accessed 13 May 2012.

Elumpe Akumu, C., Pathirana, S., Baban, S., \& Bucher, D. (2011). Examining the potential impacts of sea level rise on coastal wetlands in north-eastern NSW, Australia. Journal of Coastal Conservation, 15, 15-22.

Gregory, J. M., Church, J. A., Boer, G. J., Dixon, K. W., Flato, G. M., Jackett, D. R., Lowe, J. A., O’Farrell, S. P., Roeckner, E., Russell, G. L., Stouffer, R. J., \& Winton, M. (2001). Comparison of results from several AOGCMs for global and regional sea level change 1900-2100. Climate Dynamics, 18, 225-240.

IPCC. (2007). Summary for policymakers. Contribution of working group I to the fourth assessment report of the Intergovernmental Panel on Climate Change. In S. Solomon, D. Qin, M. Manning, Z. Chen, M. Marquis, K. B. Averyt, M. Tignor, \& H. L. Miller (Eds.), Climate change 2007: The physical science basis. Cambridge/New York: Cambridge University Press.

Jogan, N., Kaligarič, M., Leskovar, I., Seliškar, A., \& Dobravec, J. (2004). Habitatni tipi Slovenije HTS 2004 [Habitat types of Slovenia HTS 2004] - Ministrstvozaokolje, prostor in energijo, Ljubljana, pp. 1-50.

Lambeck, K., Antonioli, F., Purcell, A., \& Silenzi, S. (2004). Sea level change along the Italian coast for the past 10,000 yrs. Quaternary Science Reviews, 23, 1567e1598.

Nicholls, R. J., Hoozemans, F. M. J., \& Marchand, M. (1999). Increasing flood risk and wetland losses due to global sea level rise: Regional and global analyses. Global Environmental Change, 9(1999), 69-87.

Palazov, A., \& Stanchev, H. (2006). Evolution of human population pressure along the Bulgarian Black Sea coast. Paper presented at the first biannual scientific conference "Black Sea Ecosystem 2005 and Beyond,” 8-10 May 2006, Istanbul, Turkey, pp. 158-160. 